\title{
Ocular injuries caused by metal caps of carbonated mineral water bottles
}

\author{
Soda şişelerinin metal kapaklarının neden olduğu göz yaralanmaları
}

\author{
Fazıl Cüneyt ERDURMAN, ${ }^{1}$ Osman Melih CEYLAN, ${ }^{2}$ Volkan HÜRMERİÇ, ${ }^{2}$ \\ Alfrida PELLUMBi, ${ }^{2}$ Ali Hakan DURUKAN, ${ }^{2}$ Güngör SOBACI ${ }^{2}$
}

\section{BACKGROUND}

Bottles containing carbonated drinks are potentially hazardous to the eye. In this study, we aimed to document the clinical characteristics and visual outcomes in a series of patients with ocular injury from flying metal caps of carbonated mineral water bottles.

\section{METHODS}

Retrospective review of ocular injuries due to metal caps of carbonated mineral water bottles.

\section{RESULTS}

Sixteen eyes of sixteen patients were included in the study. All of the patients were male, with a mean age of 24 years. Ten of the patients had a history of using improper tools for bottle cap removal. The left eye was involved in twelve cases and the right eye in four cases. All patients had contusion-type closed-globe injury. Varying degrees of hyphema were observed in all patients, and vitreous hemorrhage was present in four. The visual acuity at the last follow-up was $20 / 20$ in 15 of the patients.

\section{CONCLUSION}

The use of a bottle cap opener is essential for preventing ocular damage from pressed metal caps of carbonated drinks. In addition to popularising the use of screw cap bottles, warning labels that alert consumers about the possibility of eye injury should be placed on carbonated drinks with pressed metal caps.

Key Words: Carbonated drinks; ocular trauma; pressed bottle cap.

\section{$A M A C ̧$}

Karbonatlı içecek şişeleri göz için potansiyel tehlike oluştururlar. Bu çalışmada, firlayan metal soda şişe kapakları nedeniyle göz yaralanması oluşan hastaların klinik özelliklerini ve oluşan görsel sonuçları değerlendirmeyi amaçladik.

\section{GEREC VE YÖNTEM}

Soda şișelerinin metal kapaklarının neden olduğu göz yaralanmaları geriye dönük olarak gözden geçirildi.

\section{BULGULAR}

On altı hastanın 16 gözü çalışmaya alındı. Hastaların tümü erkek ve ortalama yaş 24 yıldı. On hastada şişe kapağını uygun olmayan bir aletle açma öyküsü vardı. On iki olguda sol göz, 4 olguda sağ göz etkilenmişti. Tüm olgularda kontüzyon tipinde kapalı göz yaralanması oluşmuştu. Değişik derecelerde hifema olguların tümünde mevcuttu ve dördünde vitreus hemorajisi ile birlikteydi. Son yapılan muayenede görme keskinliği hastaların 15 'inde 20/20 düzeyindeydi.

\section{SONUÇ}

Sıkıştırılmış metal soda kapaklarına bağlı oluşan göz yaralanmalarının önlenmesinde açacak kullanılması önemlidir. Vidalı çevir-aç kapakların kullanımının yaygınlaştırılmasına ilave olarak, sıkıştırılmış metal kapaklı karbonatlı içecek şişelerinin üzerine tüketicileri olası göz yaralanmaları konusunda uyaran etiketler yerleştirilmelidir.

Anahtar Sözcükler: Karbonatlı içecekler; oküler travma; sıkışt1rılmış şişe kapağı.

\footnotetext{
${ }^{1}$ Department of Ophthalmology, Çanakkale Military Hospital, Çanakkale;

${ }^{2}$ Department of Ophthalmology, Gülhane Military Faculty of Medicine, Ankara, Turkey.
}

${ }^{1}$ Çanakkale Asker Hastanesi, Göz Kliniği, Canakkale; ${ }^{2}$ Gülhane Askeri Tıp Akademisi, Göz Hastalıkları Anabilim Dalı, Ankara, Turkey. 
Glass bottles containing carbonated drinks can cause different types of ocular injuries. Scattering glass fragments from exploding bottles are a well known cause of penetrating ocular injuries which may lead to severe visual impairment or even blindness..$^{[1-7]}$ Bottle cap and cork related ocular traumas are commonly associated with ocular contusion and rarely result in globe rupture. ${ }^{[1,3,7-10]}$ Although the use of screw cap bottles has become more common because of the reduced risk of injury, glass bottles with metal caps (pressed metal caps with corrugated edges) are still being used in most countries and present a potential danger to consumers.

In Turkey, carbonated mineral waters are usually sold in glass bottles with pressed metal caps. In this study, we aimed to document the clinical characteristics and visual outcomes in a series of patients with ocular trauma from pressed metal caps of carbonated mineral water bottles.

\section{MATERIALS AND METHODS}

This study was conducted according to an institutional ethics review board-approved protocol. We performed a retrospective chart review of all patients admitted to our department with the diagnosis of ocular injury related to carbonated mineral water bottles from January 2006 through January 2011. Data included patient age, gender, the involved eye, initial ocular findings, treatment details, follow-up time, and visual outcomes. It was also noted whether an improper tool for removal of bottle cap was used. Initial ophthalmic examination included visual acuity, slit-lamp biomicroscopy, applanation tonometry, and, if possible, dilated fundoscopy. B-mode ultrasonography was performed in eyes with hyphema and/or vitreous hemorrhage precluding the fundus view.

Hyphema was graded as follows: microhyphema, only red blood cells visible in the anterior chamber; grade 1, less than one-third of the anterior chamber; grade 2, one-third to one-half of the anterior chamber; grade 3, greater than one-half but less than the total; grade 4 , total hyphema.

\section{RESULTS}

Sixteen eyes from sixteen patients diagnosed with ocular injury from metal caps of carbonated mineral water bottles were identified in the study. All of the cases were male with a mean age of 24 years (range, 19-50 years). All injuries occurred during an attempt to open the bottle cap. The medical records provided detailed information about tools (e.g., spoon handle, lighter) used for bottle cap opening in ten of the patients. In the remaining six cases, there was no information about tools or cap removal technique. None of the patients was wearing eyeglasses at the time of injury, and none was a bystander.
The left eye was involved in twelve cases and the right in four cases. All of the patients had contusiontype closed-globe injury; one of these patients also had a corneal lamellar laceration from the corrugated edge of the metallic cap. Hyphema was the major anterior segment finding observed in all patients. Hyphema grade at presentation was recorded as microhyphema in 2 patients, grade 1 in three patients, grade 2 in six patients, grade 3 in four patients, and grade 4 in one patient. Other anterior segment changes included iris sphincter tear in five eyes, angle recession in four eyes, cataract in two eyes, mydriasis in two eyes, and iridodialysis in one eye. Retinal edema in at least one quadrant was the most frequent posterior segment finding and was observed in nine eyes. A retinal break was also found in four of these eyes. Vitreous hemorrhage was present in four cases; two cases with mild and two with moderate hemorrhage.

All patients received cyclopentolate and/or tropicamide eye drops. Topical corticosteroid therapy (prednisolone) was used in fifteen of the patients. Topical antibiotics were also given in the presence of corneal abrasion. The treatment was combined with topical and/or systemic anti-glaucomatous agents in five patients with elevated intraocular pressure $(>26$ $\mathrm{mmHg}$ ).

Three patients required surgical intervention in addition to medical treatment; one patient, in whom rebleeding was observed, had anterior chamber washout for intraocular pressure control, one patient underwent cataract extraction and intraocular lens (IOL) implantation combined with iridodialysis repair, and one patient underwent anterior vitrectomy for prolapsed vitreous into the anterior chamber and cataract extraction and IOL implantation with capsular tension ring. Retinal laser photocoagulation was performed in four patients in whom retinal break was detected.

The patients were followed-up for an average of 5 months (range, 2-12 months). The visual acuity at the last visit was 20/20 in fifteen of the patients and 20/25 in one remaining patient, who developed an epiretinal membrane. The patients' age, eye laterality, injury type and mechanism, detailed anterior and posterior segment findings, treatments, and visual outcomes are summarised in Table 1.

\section{DISCUSSION}

Here we present a retrospective review of sixteen patients who had ocular injury from flying metal caps of carbonated mineral water bottles.

In population-based studies and case series, male gender has been identified as a strong risk factor for the occurrence of ocular injury, particularly among younger males. ${ }^{[11]}$ All patients in our study were male, with a mean age of 24 years and $10(63 \%)$ of the cases 
Table 1. Details of patients with closed-globe injury from flying metal caps of carbonated mineral waters

\begin{tabular}{|c|c|c|c|c|c|c|c|c|c|c|}
\hline No & $\begin{array}{l}\text { Age } \\
\text { (years) }\end{array}$ & Eye & $\begin{array}{l}\text { Use of improper } \\
\text { tools to remove } \\
\text { the bottle cap } \\
(\mathrm{Yes} / \mathrm{No})\end{array}$ & $\begin{array}{l}\text { Anterior segment } \\
\text { findings }\end{array}$ & $\begin{array}{l}\text { Posterior } \\
\text { segment } \\
\text { findings }\end{array}$ & $\begin{array}{l}\text { IOP at } \\
\text { admission } \\
(\mathrm{mmHg})\end{array}$ & Treatment & $\begin{array}{l}\text { VA at } \\
\text { admission }\end{array}$ & $\begin{array}{l}\text { VA } \\
\text { at last } \\
\text { follow- } \\
\text { up }\end{array}$ & $\begin{array}{l}\text { Follow-up } \\
\text { (months) }\end{array}$ \\
\hline 1 & 22 & Right & No information & $\begin{array}{l}\text { Corneal edema, } \\
\text { grade } 2 \text { hyphema }\end{array}$ & No finding & 17 & $\begin{array}{l}\text { Topical corticosteroid } \\
\text { and cycloplegic }\end{array}$ & $10 / 200$ & $20 / 20$ & 3 \\
\hline 2 & 23 & Right & No information & $\begin{array}{l}\text { Corneal edema, } \\
\text { grade } 2 \text { hyphema, } \\
\text { mydriasis }\end{array}$ & $\begin{array}{l}\text { Retinal edema } \\
\text { involving } \\
\text { macula }\end{array}$ & 28 & $\begin{array}{l}\text { Topical corticosteroid } \\
\text { and cycloplegic }+ \\
\text { anti-glaucomatous agents }\end{array}$ & HM & $20 / 20$ & 6 \\
\hline 3 & 21 & Left & $\begin{array}{l}\text { Yes, lighter } \\
\text { bottom }\end{array}$ & $\begin{array}{l}\text { Grade } 3 \text { hyphema, } \\
\text { two clock hours } \\
\text { of angle recession }\end{array}$ & $\begin{array}{l}\text { Moderate } \\
\text { vitreous } \\
\text { hemorrhage }\end{array}$ & 18 & $\begin{array}{l}\text { Topical corticosteroid } \\
\text { and cycloplegic }\end{array}$ & LP & $20 / 20$ & 3 \\
\hline 4 & 25 & Right & No information & Grade 2 hyphema & No finding & 24 & $\begin{array}{l}\text { Topical corticosteroid } \\
\text { and cycloplegic }\end{array}$ & $20 / 50$ & $20 / 20$ & 4 \\
\hline 5 & 21 & Left & $\begin{array}{l}\text { Yes, } \\
\text { spoon handle }\end{array}$ & $\begin{array}{l}\text { Corneal abrasion, } \\
\text { grade } 2 \text { hyphema, } \\
\text { iris sphincter tear }\end{array}$ & $\begin{array}{l}\text { Retinal edema } \\
\text { involving } \\
\text { macula, retinal } \\
\text { hemorrhages }\end{array}$ & 17 & $\begin{array}{l}\text { Topical corticosteroid, } \\
\text { cycloplegic, and } \\
\text { antibiotic }\end{array}$ & $10 / 200$ & $20 / 20$ & 3 \\
\hline 6 & 21 & Left & $\begin{array}{l}\text { Yes, } \\
\text { spoon handle }\end{array}$ & $\begin{array}{l}\text { Corneal abrasion } \\
\text { and edema, } \\
\text { microhyphema, } \\
\text { iris sphincter tear }\end{array}$ & No finding & 38 & $\begin{array}{l}\text { Topical corticosteroid, } \\
\text { cycloplegic, antibiotic }+ \\
\text { anti-glaucomatous agents }\end{array}$ & $20 / 50$ & $20 / 20$ & 3 \\
\hline 7 & 26 & Left & $\begin{array}{l}\text { Yes, } \\
\text { lighter bottom }\end{array}$ & Grade 1 hyphema & $\begin{array}{l}\text { Retinal edema, } \\
\text { retinal } \\
\text { hemorrhages }\end{array}$ & 25 & $\begin{array}{l}\text { Topical corticosteroid } \\
\text { and cycloplegic }\end{array}$ & $20 / 20$ & $20 / 20$ & 2 \\
\hline 8 & 21 & Left & No information & $\begin{array}{l}\text { Grade } 3 \text { hyphema, } \\
\text { iridodialysis, } \\
\text { cataract }\end{array}$ & $\begin{array}{l}\text { Retinal edema, } \\
\text { retinal hole }\end{array}$ & 22 & $\begin{array}{l}\text { Topical corticosteroid } \\
\text { and cycloplegic }+ \\
\text { Lens extraction, IOL } \\
\text { implantation, iridodialysis } \\
\text { repair + LPC }\end{array}$ & $5 / 200$ & $20 / 20$ & 5 \\
\hline 9 & 19 & Left & $\begin{array}{l}\text { Yes, } \\
\text { spoon handle }\end{array}$ & $\begin{array}{l}\text { Lamellar corneal } \\
\text { laceration, grade } 3 \\
\text { hyphema }\end{array}$ & $\begin{array}{l}\text { Retinal edema } \\
\text { involving } \\
\text { macula }\end{array}$ & 15 & $\begin{array}{l}\text { Topical corticosteroid, } \\
\text { cycloplegic and antibiotic }\end{array}$ & LP & $20 / 20$ & 8 \\
\hline 10 & 20 & Right & No information & $\begin{array}{l}\text { Grade } 2 \text { hyphema, } \\
\text { iris sphincter tear, } \\
360 \text { degrees of } \\
\text { angle recession }\end{array}$ & $\begin{array}{l}\text { Retinal edema, } \\
\text { mild vitreous } \\
\text { hemorrhage, } \\
\text { retinal } \\
\text { hemorrhages, } \\
\text { retinal hole }\end{array}$ & 10 & $\begin{array}{l}\text { Topical corticosteroid and } \\
\text { cycloplegic }+ \text { LPC }\end{array}$ & $20 / 30$ & $20 / 25^{\dagger}$ & 12 \\
\hline 11 & 20 & Left & $\begin{array}{l}\text { Yes, } \\
\text { lighter bottom }\end{array}$ & $\begin{array}{l}\text { Grade } 1 \text { hyphema, } \\
\text { iris sphincter tear }\end{array}$ & No finding & 11 & $\begin{array}{l}\text { Topical corticosteroid and } \\
\text { cycloplegic }\end{array}$ & $20 / 25$ & $20 / 20$ & 2 \\
\hline 12 & 24 & Left & No information & $\begin{array}{l}\text { Grade } 3 \text { hyphema, } \\
\text { two clock hours } \\
\text { of angle recession }\end{array}$ & $\begin{array}{l}\text { Retinal edema } \\
\text { involving } \\
\text { macula, retinal } \\
\text { hemorrhages }\end{array}$ & 40 & $\begin{array}{l}\text { Topical corticosteroid and } \\
\text { cycloplegic }+ \\
\text { anti-glaucomatous agents+ } \\
\text { Anterior chamber washout } \\
\text { for IOP control }{ }^{\ddagger}\end{array}$ & $\mathrm{HM}$ & $20 / 20$ & 6 \\
\hline 13 & 21 & Left & $\begin{array}{l}\text { Yes, } \\
\text { lighter bottom }\end{array}$ & Grade 2 hyphema & No finding & 49 & $\begin{array}{l}\text { Topical corticosteroid and } \\
\text { cycloplegic }+ \\
\text { anti-glaucomatous agents }\end{array}$ & $20 / 50$ & $20 / 20$ & 3 \\
\hline 14 & 25 & Left & $\begin{array}{l}\text { Yes, } \\
\text { lighter bottom }\end{array}$ & $\begin{array}{l}\text { Corneal abrasion, } \\
\text { grade } 1 \text { hyphema, } \\
\text { mydriasis }\end{array}$ & $\begin{array}{l}\text { Retinal edema, } \\
\text { mild vitreous } \\
\text { hemorrhage, } \\
\text { retinal } \\
\text { hemorrhages, } \\
\text { retinal tear }\end{array}$ & 11 & $\begin{array}{l}\text { Topical corticosteroid, } \\
\text { cycloplegic, antibiotic + } \\
\text { LPC }\end{array}$ & $20 / 40$ & $20 / 20$ & 7 \\
\hline 15 & 27 & Left & Yes, & $\begin{array}{l}\text { Corneal abrasion, } \\
\text { microhyphema }\end{array}$ & $\begin{array}{l}\text { Retinal edema, } \\
\text { retinal tear }\end{array}$ & 15 & $\begin{array}{l}\text { Cycloplegic + antibiotic } \\
\text { LPC }\end{array}$ & $20 / 20$ & $20 / 20$ & 2 \\
\hline 16 & 50 & Left & $\begin{array}{l}\text { Yes, } \\
\text { spoon handle }\end{array}$ & $\begin{array}{l}\text { Grade } 4 \text { hyphema, } \\
\text { vitreous prolapse } \\
\text { into anterior } \\
\text { chamber, iris } \\
\text { sphincter tear, } \\
270 \text { degrees of angle } \\
\text { recession, zonular } \\
\text { dialysis, cataract }\end{array}$ & $\begin{array}{l}\text { Moderate } \\
\text { vitreous } \\
\text { hemorrhage }\end{array}$ & $16^{\S}$ & $\begin{array}{l}\text { Topical corticosteroid and } \\
\text { cycloplegic }+ \\
\text { anti-glaucomatous agents }+ \\
\text { Anterior vitrectomy for } \\
\text { vitreous prolapse into } \\
\text { anterior chamber, cataract } \\
\text { extraction and IOL } \\
\text { implantation using CTR }\end{array}$ & LP & $20 / 20$ & 6 \\
\hline
\end{tabular}

CTR: Capsular tension ring; IOL: Intraocular lens; IOP: Intraocular pressure; LP: Light perception; LPC: Laser photocoagulation; VA: Visual acuity. $\dagger$ Epiretinal membrane was observed 6 months after injury; $\ddagger$ Rebleeding occurred within 2 days and anterior chamber washout was carried out 7 days after injury; $\S$ IOP increased to $45 \mathrm{mmHg}$ 13 days after injury. 
had a history of using improper tools (i.e., bottom end of the lighter or spoon handle) to open the metallic cap. Data about the reasons for not using a bottle cap opener were not available in the medical records, and therefore, we could not define why improper tools were used for bottle cap opening. However, an Internet search showed that there are many websites demonstrating how to open the pressed metallic cap without using a bottle opener. Given the risk-taking attitudes and tendency to engage in more risky activities, young males seem to be prone to these types of injuries.

In our study group, the left eye was involved in $12(75 \%)$ of the sixteen patients. In previous reports on injuries caused by bottle cap and corks, no difference was reported in the laterality of eye involvement. ${ }^{[1,3,9,10]}$ However, in a report on champagne cork injury, it was found that the left eye was more likely to be involved, and the predominance of left-sided injury was explained by the bottle position resulting from the right-hand dominance. ${ }^{[8]}$ When attempting to open the bottle using the dominant right hand, the bottle is held with the left hand and kept on the left side of the body, such that the right eye is partially protected from the flying bottle cap by the nose.

A bottle cap or cork hitting the eye can damage the anterior and posterior segment structures of the eye via direct tissue compression at the impact site (coup injury) as well as indirect effects at the site opposite the impact (contrecoup injury). Hyphema is one of the frequent findings observed following bottle-cap or cork trauma. ${ }^{[8,9]}$ In our study, varying degrees of hyphema were noted in all cases following the trauma. Hyphema was recorded as grade 2 in six of the patients. Rebleeding was documented in one patient with grade 3 hyphema and anterior chamber washout was required for intraocular pressure control. In our previous report, retinal detachment was found to be the most frequent posterior segment pathology related to contusion type ocular trauma. ${ }^{[12]}$ In current study, a retinal break was found in four patients and surrounded with laser photocoagulation. In one patient, who also had mild vitreous hemorrhage, an epiretinal membrane was observed six months after the injury.

In Turkey, the production of carbonated mineral waters has increased approximately two-fold in the last five years. ${ }^{[13]}$ Carbonated mineral waters are most commonly sold in metal-capped non-returnable glass bottles of $20 \mathrm{cl}$; however, there is no warning label on the bottles about cap-related injuries resulting from use of improper tools or opening techniques. Given the rapidly increasing consumption of glass-bottled carbonated mineral water with pressed metal caps, a conspicuous warning label indicating possible eye damage and illustrating a safe bottle-opening technique is essential for preventing eye injuries. Based on the results of this study, as well as previous published reports, we are planning to contact the National Association of Mineral Water Manufacturers to inform them about the possible hazards of pressed metallic bottle caps and the importance of warning label placement on bottles.

In the current study, visual acuity at last followup was 20/20 in all patients except one, in whom an epiretinal membrane was identified 6 months after injury. In a review of 34 cases with bottle cork and cap-related closed-globe injury, Cavallini et al. ${ }^{[9]}$ reported that metal caps were not found to be associated with poor visual outcome (20/40 or less). It was suggested that the lighter weight and smaller size of the metallic caps were less associated with severe damage when compared to natural or plastic corks. ${ }^{[9]}$ Although there were no patients with an open-globe injury in our study group, given the patient with corneal lamellar laceration, the relatively sharp edges of the metal caps are also likely to cause a full-thickness globe injury that may be associated with severe visual impairment.

The limitations of our study include the retrospective design and relatively short follow-up period with regard to long-term complications. The data collected from medical records did not include detailed information about predisposing factors related to bottle cap related injury, such as shaking or heating the bottle before opening the cap.

In conclusion, almost all such ocular injuries can be avoided with the use of a bottle cap opener with an appropriate technique. As a technique for the opening of a bottle, tightly holding the bottle with one hand and firmly covering of both the metallic cap and the cap opener from the top of the bottle with the other hand seems a safe way to prevent eye damage. In addition to increasing the use of screw cap bottles by the manufacturers, the carbonated mineral water bottles with metal caps should carry a warning label to alert consumers about the possibility of eye injury.

Conflict-of-interest issues regarding the authorship or article: None declared.

\section{REFERENCES}

1. Al Salem M, Sheriff SM. Ocular injuries from carbonated soft drink bottle explosions. Br J Ophthalmol 1984;68:281-3.

2. Gupta AK, Moraos O. Ocular injuries due to accidental explosion of carbonated beverage bottles. Indian J Ophthalmol 1982;30:47-50.

3. Kuhn F, Mester V, Morris R, Dalma J. Serious eye injuries caused by bottles containing carbonated drinks. Br J Ophthalmol 2004;88:69-71.

4. Mondino BJ, Brown SI, Grand MG. Ocular injuries from exploding beverage bottles. Arch Ophthalmol 1978;96:2040-1.

5. Schrader WF, Gramer E. Open globe injuries induced by glass bottles containing carbonated drinks. Graefes Arch Clin Exp Ophthalmol 2010;248:313-7. 
6. Sellar PW, Johnston PB. Ocular injuries due to exploding bottles of carbonated drinks. BMJ 1991;303:176-7.

7. Spang S, Höh H, Ruprecht KW. Eye injuries caused by opening or explosion of beverage bottles. Ophthalmologe 1995;92:35-7. [Abstract]

8. Archer D, Galloway N. Champagne-cork injury to the eye. Lancet 1967;2:487-9.

9. Cavallini GM, Martini A, Campi L, Forlini M. Bottle cork and cap injury to the eye: a review of 34 cases. Graefes Arch Clin Exp Ophthalmol 2009;247:445-50.

10. Viestenz A, Küchle M. Eye contusions caused by a bottle cap. A retrospective study based on the Erlangen Ocular Contusion Register (EOCR). Ophthalmologe 2002;99:1058. [Abstract]

11. Négrel AD, Thylefors B. The global impact of eye injuries. Ophthalmic Epidemiol 1998;5:143-6

12. Erdurman FC, Sobaci G, Acikel CH, Ceylan MO, Durukan AH, Hurmeric V. Anatomical and functional outcomes in contusion injuries of posterior segment. Eye (Lond) 2011;25:1050-6.

13. Turkish Statistical Institute. Turkey's Statistical Yearbook, 2010. Available from: http://www.turkstat.gov.tr. 